KA N D A I

\begin{tabular}{|l|l|l|}
\hline Volume 16 & No. 2, November 2020 & Halaman 217-230 \\
\hline
\end{tabular}

\title{
REFLEKSI REFORMASI PERILAKU MASYARAKAT \\ DALAM CERPEN "KARANGAN BUNGA DARI MENTERI" \\ KARYA SENO GUMIRA AJIDARMA \\ (Reflection on Community Behavior Reform in The Short Story \\ "Karangan Bunga dari Menteri” by Seno Gumira Ajidarma)
}

\author{
Ninawati Syahrul \\ Badan Pengembangan dan Pembinaan Bahasa \\ Jalan Daksinapati Barat IV, Rawamangun, Jakarta Timur, Indonesia \\ Pos-el: ninawatysyahrul.bahasa@gmail.com
}

(Diterima: 27 Desember 2018; Direvisi: 7 Mei 2020; Disetujui: 30 Oktober 2020)

\begin{abstract}
The problem revealed in this study is how is social criticism of the depravity of the behavior of state officials and / or members of the community itself contained in the short story "Garlands of Ministers" by Seno Gumira Ajidarma? This study aims to describe the social criticism of the depravity of the behavior of state officials and / or members of the community itself contained in the short story "Wreath of the Minister" by Seno Gumira Ajidarma. This study uses a descriptive qualitative interpretive method. The elaboration uses a sociological approach to literature from the viewpoint of social and cultural aspects. The research data are in the form of narrative texts and dialogues in "Garlands of Ministers" by Seno Gumira Ajidarma. Data collection techniques using literature study by listening and noting the main issues that will be decomposed. Data analysis techniques used heuristic and hermeneutic reading methods. The results showed that the social criticism concerned was criticism of government presented in a fairly subtle, but open way. In this case the author symbolizes it with the figure of a minister who is so busy with his work affairs that he considers the marriage invitation addressed to him unimportant. In this short story, Seno Gumira Ajidarma's expertise in processing his social criticism was wrapped with neat storylines and characterizations. The author appears as a figure of "social social judge" in caring for and guarding the life of a civilized society.
\end{abstract}

Keywords: short stories, social criticism, sociology of literature.

Abstrak

Masalah yang diungkap dalam karya tulis ilmiah ini adalah bagaimanakah kritik sosial atas kebobrokan perilaku pejabat negara dan/atau anggota masyarakat yang terkandung dalam cerpen "Karangan Bunga dari Menteri" karya Seno Gumira Ajidarma? Karya tulis ilmiah ini bertujuan untuk mendeskripsikan kritik sosial atas kebobrokan perilaku pejabat negara dan/atau anggota masyarakat yang terkandung dalam cerpen "Karangan Bunga dari Menteri" karya Seno Gumira Ajidarma. Karya tulis ilmiah ini menggunakan metode deskriptif kualitatif interpretatif. Dikaji menggunakan pendekatan sosiologi sastra dari tinjauan aspek sosial dan budaya. Data karya tulis ilmiah berupa teks narasi dan dialog dalam "Karangan Bunga dari Menteri" karya Seno Gumira Ajidarma. Teknik pengumpulan data menggunakan studi pustaka dengan cara menyimak dan mencatat pokok persoalan yang akan dikaji. Teknik analisis data menggunakan metode pembacaan heuristik dan hermeneutika. Hasil karya tulis ilmiah menunjukkan kritik sosial yang dimaksud adalah kritikan terhadap pemerintahan yang disajikan dengan cara yang cukup halus, tetapi terbuka. Dalam hal ini, pengarang melambangkannya dengan sosok seorang menteri yang sangat sibuk dengan urusan pekerjaannya sehingga menganggap undangan pernikahan yang dialamatkan kepadanya tidak penting. Dalam cerpen itu, tampak kepiawaian Seno Gumira Ajidarma dalam mengolah kritik sosial yang dibalut dengan alur cerita dan 
penokohan yang apik. Pengarang tampil sebagai sosok "hakim sosial kemasyarakatan" dalam merawat dan mengawal kehidupan masyarakat yang berbudaya.

Kata-kata kunci: cerpen, kritik sosial, sosiologi sastra

DOI: $10.26499 / j k . v 16 i 2.1126$

How to cite: Syahrul, N. (2020). Refleksi reformasi perilaku masyarakat dalam cerpen "Karangan Bunga dari Menteri" karya Seno Gumira Ajidarma. Kandai, 16(2), 217-230 (DOI: 10.26499/jk.v16i2.1126)

\section{PENDAHULUAN}

Cerpen berjudul "Karangan Bunga dari Menteri" karya Seno Gumira Ajidarma menceritakan episode kekuasaan di Indonesia. Di Indonesia, kebiasaan mengirim karangan bunga sebagai simbol untuk selebrasi pernikahan, pelantikan pejabat, ulang tahun, peresmian gedung, dan kematian telah menjadi tradisi panjang meski jarang bermakna (Ajidarma, 2011).

Karangan bunga diartikan sebagai keindahan dan kewangian dalam berdemokrasi. Pada karangan bunga, kadang didapati pita hitam sebagai lambang duka. Dua episode bersejarah 1965 dan 1998 telah berlalu. Sekarang, sebagian orang masih terus memikirkan kebermaknaan karangan bunga. Papan karangan bunga tidak lagi sebagai bentuk ucapan selamat, melainkan sudah menjelma menjadi sebuah prestise bagi yang punya pesta. Tanpa kehadiran papan karangan bunga maka pesta terasa tidak meriah.

Tidak tahu pasti sejak kapan tren papan karangan bunga ucapan selamat di pesta pernikahan mulai mewabah. Sebelum tahun 2000-an pemberian karangan bunga masih langka terlihat. Belakangan, tren ini semakin menjadijadi, seakan menjadi sebuah prestise bagi pemilik hajatan apabila pestanya dibanjiri papan karangan bunga. Apalagi bila terdapat papan karangan bunga dari pejabat berpengaruh, seperti wali kota, bupati, gubernur, menteri. atau presiden, pasti papan karangan bunga itu akan ditempatkan pada posisi sangat strategis yang dapat dilihat dan dibaca oleh para undangan yang datang. Papan karangan bunga pada acara pesta pernikahan akan memberi nuansa pesta terlihat lebih meriah walaupun hanya terbuat dari busa dan kertas yang berwarna-warni. Setiap orang pasti pernah melihat sebuah pesta pernikahan dibanjiri dengan papan karangan bunga di lokasi pesta, hanya sebagai penanda bahwa si empunya hajat merupakan orang penting yang punya banyak relasi dan klien.

Seno dalam cerpennya, "Karangan Bunga dari Menteri", menghadirkan lambang berupa karangan bunga. Pengarang ini sering menghadirkan lambang sebagai penyampai ide, pemikiran, gagasan, dan pesan dalam karyanya. Hal yang menarik dari pengarang ini adalah suguhan kemampuan pengarang dalam mengolah gagasan dengan melihat sisi lain dari kehidupan para pejabat negara dan digunakan sebagai gagasan dalam penulisan cerpen ini. Selain itu, digunakan pula latar pemerintahan dengan simbol atau lambang sebagai ide atau gagasan penceritaan. Karya sastra yang ditulisnya berjudul "Rupadi" juga sebagai simbol perlawanan terhadap kuasa patriarki. Demikian pula dalam novel Drupadi: Perempuan Poliandris, Seno ingin menunjukkan wacana simbolis perlawanan tersebut. Tokoh Drupadi menuntut kesetaraan antara laki-laki dan perempuan kepada Pandawa karena dirinya selalu mengabdi kepada mereka. Drupadi mengatakan kepada Pandawa bahwa mereka tidak pernah menyetarakan laki-laki dan perempuan (Ekasaputra, 2018:322). Secara etimologis, symbol berasal dari 
bahasa Yunani, symballein yang berarti 'tindakan (act) melukiskan lapis-lapis makna kias' (Jenks, 2013). Tindakan simbolis dalam karya sastra terdapat dalam interaksi sosial dan kultural antar tokoh.

Simbol adalah bentuk yang menandai sesuatu yang lain di luar perwujudan bentuk simbolis itu sendiri. Simbol yang tertuliskan sebagai bunga misalnya, mengacu dan mengemban gambaran fakta yang disebut "bunga" sebagai sesuatu yang ada di luar bentuk simbolis itu sendiri (Sobur, 2009).

Nama Seno Gumira Ajidarma di dunia sastra, khususnya cerpen, memang sudah tidak asing lagi. Seno merupakan pengarang cerpen yang sudah memiliki banyak karya terkenal yang ditebitkan secara nasional. Cerpen "Karangan Bunga dari Menteri" merupakan cerpen yang sarat dengan kritik sosial terhadap kehidupan para pejabat negara.

Cerita pendek atau cerpen merupakan salah satu bentuk karya sastra di samping novel, puisi, dan drama. Perkembangan cerpen di Indonesia pada dekade 90-an lebih maju jika dibandingkan dengan tahun-tahun sebelumnya. Hal ini terbukti dengan banyaknya media massa yang memuat cerpen dalam setiap penerbitannya. Salah satu media itu adalah surat kabar Kompas. Penerbitan cerpen dalam surat kabar Kompas muncul setiap hari Minggu dan menerbitkan cerpen pilihan setiap minggunya. Salah satu dari cerpen pilihan itu adalah "Karangan Bunga dari Menteri” (Ajidarma, 2011).

Cerpen "Karangan Bunga dari Menteri" karya Seno Gumira Ajidarma ini unik dan menarik untuk diteliti karena Seno mengandalkan perspektif terhadap simbolisme yang hadir di luar struktural cerita yang diciptakan. Cerpen ini sangat sarat akan unsur sindiran dan kritikan terhadap pemerintahan yang disajikan dengan cara yang cukup halus, tetapi terbuka.

Kritik sosial dalam sastra indentik pula dengan dominannya masalah sosial dalam kehidupan di luar sastra (Sarjono, 2001). Menurut Kartono (2013:2) masalah sosial adalah semua tingkah laku yang melanggar atau memerkosa adat istiadat masyarakat dan dianggap oleh sebagian besar masyarakat sebagai pengganggu, sesuatu yang tidak dikehendaki, berbahaya, dan merugikan orang banyak. Setiap individu pada dasarnya memiliki dua hal yang terus berdampingan dalam dirinya, yaitu permasalahan dan kebutuhan. Permasalahan akan terus ada selama manusia memiliki kebutuhan. Menurut Endraswara (2019:xv) untuk memecahkan persoalan sosial dalam karya sastra, diperlukan teori kritis kolaboratif yang disebut sosiologi sastra. Hal ini berkaitan dengan kebiasaan sastrawan yang sering "gila" mengangkat peristiwa sosial yang hangat, berkaitan dengan kekuasaan dan aspek-aspek kultural. Persoalan sosial dalam karya sastra merupakan endapan pengalaman simbolis yang perlu ditafsirkan. Makna aktivitas sosial, seperti sastra, perlu ditafsirkan secara simbolis. Dengan kata lain, masalah sosial bukan merupakan sesuatu yang pasti dan mutlak karena masalah sosial sangat bergantung pada keadaan masyarakatnya.

Permasalahan dalam sastra tidak semata-mata merupakan permasalahan yang imajinatif. Permasalahan itu didasari permasalahan yang hidup di sekeliling sastra itu dilahirkan. Bagaimanapun juga, pengarang merupakan salah satu anggota masyarakat dan melalui karya sastranya dapat dijadikan cermin kehidupan serta diperoleh pelajaran karena karya sastra itu mengandung ajaran moral atau didaktis, estetika, dan berbagai hal yang 
menyangkut tata pergaulan sesama umat manusia (Kosasih, 2012). Karya sastra banyak memuat kritik di dalamnya. Sastra yang mengandung pesan kritik dalam penyampaiannya dapat juga disebut sastra kritik. Sastra kritik biasanya akan lahir di tengah masyarakat jika terjadi hal-hal yang kurang beres dalam kehidupan sosial dan masyarakat (Nurgiyantoro, 2010).

Secara struktural, cerpen ini tidak mempunyai sesuatu yang berbeda dengan cerpen lainnya. Penggambaran tokoh, alur, dan latar tampak biasa-biasa saja. Apabila dilihat sepintas lalu, cerpen ini tampaknya sederhana, hanya menceritakan seorang menteri yang selalu mendapatkan banyak undangan dan berinisiatif mengirim karangan bunga kepada orang-orang yang mengundangnya sebagai pengganti kehadirannya. Hal yang menarik sebenarnya adalah kemampuan Seno dalam mengolah ide dengan melihat sisi lain dari kehidupan para pejabat negara sebagai ide dalam penulisan cerpen ini.

Pembicaraan tentang cerpen "Karangan Bunga dari Menteri" karya Seno Gumira Ajidarma pernah dilakukan antara lain oleh Kim Devi, 10 November 2013, berjudul "Analisis Perbandingan Teori Hegemoni Cerpen 'Karangan Bunga dari Menteri' Karya Seno Gumira Ajidarma dengan Cerpen 'Pemburu' karya Agus Noor". Simpulan penelitian, yaitu cerpen "Karangan Bunga dari Menteri" karya Seno Gumira Ajidarma dan "Pemburu" karya Agus Noor memiliki kesamaan dalam hal kekuasaan atau hegemoni yang kuat. Pada Cerpen "Karangan Bunga dari Menteri" karya Seno Gumira Ajidarma, kekuasaan terletak pada sebuah kehidupan seorang menteri yang membanggakan kekuasaan di atas segala-galanya. Pengarang menggambarkan langsung tokoh atau objek yang dimaksud dengan ide masyarakat hanya sebagai batu loncatan untuk memiliki kekuasaan, sedangkan dalam Cerpen "Pemburu" karya Agus Noor, pengarang menggambarkan secara tidak langsung, yaitu menggunakan ilustrasi tokoh-tokoh penguasa seperti hewan buas pemangsa. Persamaan dari dua cerpen tersebut adalah penggambaran kekuasaan dan pejabat pemerintahan yang gila dengan kedudukan tanpa memperhatikan sekitar. Perbedaan dari kedua cerpen tersebut, yaitu dalam cerpen "Karangan Bunga dari Menteri" karya Seno Gumira Ajidarma, tokoh yang digambarkan hanya memperhatikan kekuasaan tanpa memperhatikan lingkungan atau masyarakat sekitar. Masyarakat kedudukannya hanya formalitas aja, masyarakat tidak dianggap penting. Bagi seorang menteri yang terpenting adalah kekuasaan dan kedudukannya saja. Pengarang dalam cerpen "Pemburu" mengilustrasikan tokoh pemburu sebagai hewan pemangsa, unsur hegemoni yang mengarah pada kekuasaaan dan kekerasan. Cerpen tersebut menggambarkan kekuasaan merupakan hal utama dalam mempertahankan kedudukan meskipun nyawa rakyat dikorbankan. Tidak segan-segan mereka membuat rakyat menjadi budak dan tameng di negeri ini. Dalam memengaruhi para pejabat pemerintahan, para pemburu memberi iming-iming kekuasaan, tetapi apabila mereka tidak mengikuti keinginannya, mereka tidak segan-segan membunuhnya. Terdapat unsur kekerasan yang membuat para penguasa hidup bebas di dunia ini (Devi, 2013). Rahman (2018) dalam artikelnya yang berjudul "Komparasi Dekonstruksi Simbolisme dalam Cerpen 'Padang Kurusetra' karya Emha Ainun Nadjib dan 'Karangan Bunga dari Menteri' karya Seno Gumira Ajidarma" menyimpulkan sebagai berikut. Pertama, kedua pengarang sama-sama 
menggunakan simbol-simbol dalam karyanya. Kedua, ide yang menjadi dasar penceritaan kedua karya memiliki kemiripan, yaitu kondisi sosial kemasyarakatan yang menyangkut berbagai masalah pemerintahan. Ketiga, secara dekonstruksi dapat dilihat kemiripan maksud pengarang dari sisi lain. Keempat, kedua pengarang memiliki kemiripan pola pikir dan kepekaan yang tinggi terhadap lingkungan sosial. Penelitian ini lebih menitikberatkan aspek-aspek sosiohistoris dalam cerpen. Sosiohistoris juga tidak akan lepas dari aspek politik dan kekuasaan (Endraswara, 2013). Hal ini menandai bahwa kajian sosiohistoris cerpen lebih terfokus pada lingkungan sosial dan kekuasaan. Perbedaan penelitian ini dengan penelitianpenelitian sebelumnya adalah mengenai gagasan yang terdapat dalam cerpen "Karangan Bunga dari Menteri" karya Seno Gumira Ajidarma, yaitu sebagai kritik sosial atas kebobrokan perilaku pejabat negara dan/atau anggota masyarakat. Hal tersebut belum diungkap pada penelitian terdahulu.

Masalah yang diungkap dalam penelitian ini adalah bagaimanakah kritik sosial atas kebobrokan perilaku pejabat negara dan/atau anggota masyarakat yang terkandung dalam cerpen "Karangan Bunga dari Menteri" karya Seno Gumira Ajidarma? Karya tulis ilmiah ini bertujuan untuk untuk mendeskripsikan kritik sosial atas kebobrokan perilaku pejabat negara dan/atau anggota masyarakat yang terkandung dalam cerpen "Karangan Bunga dari Menteri" karya Seno Gumira Ajidarma.

\section{LANDASAN TEORI}

\section{Hakikat Cerpen}

Menurut Priyatni (2010:126), cerita pendek adalah salah satu bentuk karya fiksi. Cerita pendek, sesuai dengan namanya, memperlihatkan sifat yang serba pendek, baik peristiwa yang diungkapkan, isi cerita, jumlah pelaku, dan jumlah kata yang digunakan. Perbandingan ini akan tampak jika dikaitkan dengan bentuk prosa yang lain, misalnya novel. Sesuai dengan namanya, cerita pendek dapat diartikan sebagai cerita berbentuk prosa yang pendek (Suyanto, 2012). Jadi, dapat disimpulkan, cerita pendek atau cerpen adalah sebuah karangan berbentuk prosa fiksi yang habis dibaca sekali duduk atau tidak membutuhkan waktu lama untuk menyelesaikan satu cerita.

\section{Hakikat Sosiologi Sastra}

Teori utama yang dipergunakan untuk menganalisis permasalahan, kritik sosial, adalah teori sosiologi sastra. Menurut Endraswara (2012), sosiologi sastra secara harfiah mesti ditopang oleh dua konsep yang berbeda, yaitu konsep sosiologi dan konsep sastra. Masalah yang perlu dipertimbangkan adalah dominasinya dalam analisis sehingga tujuan yang dimaksud dapat tercapai secara maksimal. Dalam sosiologi sastra, seharusnya didominasi oleh konsep yang berkaitan dengan sastra, sedangkan konsep yang berkaitan dengan sosiologi berfungsi sebagai komplementer.

Jabrohim. dkk. (2001:169)

berpendapat bahwa tujuan penelitian sosiologi sastra adalah untuk mendapatkan gambaran yang lengkap, utuh, dan menyeluruh tentang hubungan timbal balik antara sastrawan, karya sastra, dan masyarakat. Sosiologi sastra berasal dari kata sosiologi dan sastra. 
Sosiologi berasal dari bahasa Yunani, akar kata socius berarti 'bersama-sama, bersatu, kawan, dan teman' dan logos berarti 'sabda, perkataan perumpamaan'.

Menurut Fananie (2002:132), sosiologi adalah ilmu pengetahuan yang objek studinya berupa aktivitas sosial manusia. Sastra dapat dipandang sebagai suatu gejala sosial. Damono (2003:1) mengatakan bahwa studi sosiologi sastra sering didefinisikan sebagai pendekatan yang memahami dan menilai karya sastra dengan mempertimbangkan segi kemasyarakatan atau sosial. Sastra bukanlah sekadar pencerminan masyarakatnya. Sastra merupakan usaha manusia untuk menemukan makna dunia atas nilai yang terkandung di dalam sastra. Nilai itu harus dihayati oleh orang dan masyarakat (Faruk, 2012).

Apabila dilihat dari namanya, sosiologi sastra terdiri atas kata sosiologi dan sastra. Hal itu berarti bahwa sosiologi sastra adalah suatu ilmu yang bersifat interdisipliner. Karya sastra sendiri merupakan sebuah dokumen sosial karena memiliki unsur cerita/isi yang berkaitan dengan masalah sosial. Sastra juga mempunyai kemampuan untuk mencatat kenyataan sosiokultural suatu masyarakat pada masa tertentu, baik sosiologi maupun sastra. Keduanya memiliki kajian yang sama, yaitu manusia dalam masyarakat.

Menurut Wellek dan Warren (2014:84), penelitian yang menggunakan pendekatan sosiologi sastra dapat dibedakan atas tiga permasalahan, yaitu (1) sosiologi pengarang yang memusatkan permasalahan kepada status sosial, ideologi sosial, dan lain-lain yang menyangkut pengarang sebagai penghasil cerita; (2) sosiologi sastra yang memusatkan perhatian kepada karya itu sendiri dengan memfokuskan penelaahan kepada isi karya sastra tersebut, baik apa yang tersirat dan apa yang menjadi tujuannya; dan sosiologi sastra yang memusatkan permasalahan pada pembaca serta pengaruh sosial karya sastra.

Penelitian ini hanya membicarakan permasalahan kedua, yaitu pemusatan permasalahan pada karya dengan memfokuskan penelaahan kepada isi karya sastra tersebut. Hal yang akan dibicarakan adalah reformasi perilaku masyarakat. Namun, perlu disadari bahwa untuk menghindari pembicaraan permasalan pertama dan tiga tidak mungkin dapat dilaksanakan sepenuhnya. Oleh karena itu, pembicaraan yang menyingung kedua permasalahan itu, dimaksudkan sebagai pelengkap dari gejala yang dibicarakan.

\section{METODE PENELITIAN}

Karya tulis ilmiah ini
menggunakan kualitatif interpretatif. Penguraiannya menggunakan pendekatan sosiologi sastra dari sudut tinjau aspek sosial dan budaya. Data penelitian berupa teks narasi dan dialog dalam "Karangan Bunga dari Menteri" karya Seno Gumira Ajidarma. Teknik pengumpulan data menggunakan studi pustaka dengan cara menyimak dan mencatat pokok persoalan yang akan diurai. Teknik analisis data menggunakan metode pembacaan heuristik dan hermeneutika. Langkah-langkah yang dilakukan untuk keperluan itu adalah sebagai berikut.

1) Menentukan cerpen yang dijadikan objek, yaitu "Karangan Bunga Dari Menteri” karya Seno Gumira Ajidarma yang diterbitkan oleh surat kabar Kompas pertama kali pada tahun 2011.

2) Menetapkan masalah pokok, yaitu tentang kritik sosial yang terkesan digugat dari sudut pandang kehidupan modern sekarang ini.

3) Melakukan studi pustaka dengan mencari dan mengumpulkan bahan 
yang mendukung objek analisis. Pustaka yang dimaksud ialah yang berkaitan dengan analisis pendekatan ekstrinsik berlandaskan pada teori sosiologi sastra yang menyatakan adanya hubungan antara karya sastra dengan masyarakat. Terdapat hubungan antara karya satra dan masyarakat inilah yang membuat penelitian ini menggunakan pendekatan sosiologi sastra dalam menganalisis "Karangan Bunga Dari Menteri” karya Seno Gumira Ajidarma.

4) Menganalis cerpen yang menjadi objek dengan analisis sosiologi sastra.

5) Merumuskan hasil penelitian tersebut.

\section{PEMBAHASAN}

\section{Sinopsis Cerpen "Karangan Bunga dari Menteri” Karya Seno Gumira Ajidarma}

Cerpen "Karangan Bunga dari Menteri" bercerita tentang fenomena polah tingkah masyarakat di perkotaan di kalangan orang berada. Cerita dimulai ketika istri seorang pemborong merasa mual diperlambang dengan rasa ingin muntah atas tingkah laku suaminya yang lebih mementingkan karangan bunga yang dikirim oleh tiga orang menteri pada saat pesta pernikahan anak mereka. Tiga orang menteri inilah yang selama ini menyetujui proyek yang dikerjakan suaminya. Oleh karena itulah, kepentingan yang lebih besar untuk memperlihatkan karangan bunga dari menteri mengalahkan rasa sentimental istrinya terhadap karangan bunga dari sahabatnya sedari kecil. Padahal, dalam bagian lain, bagaimana galau dan geram hati sang menteri yang mendapat setumpuk undangan yang entah dari mana datangnya, tetapi mengharapkan kedatangannya. Sang menteri merasa tidak penting menghadiri pesta pernikahan tersebut sehingga hanya dengan mengirimkan karangan bunga dirasa cukup sebagai wakil kehadirannya. Baginya, dengan karangan bunga dari menteri sudah cukup memperlihatkan dirinya sebagai seseorang yang terhormat dan berpengaruh.

\section{Biografi Seno Gumira Ajidarma}

Seno Gumira Ajidarma dilahirkan di Boston pada tanggal 19 Juni 1958 dan dibesarkan di Yogyakarta. Pada tahun 1977, Seno pindah ke Jakarta dan kuliah di Departemen Sinematografi Lembaga Kesenian Jakarta (kini IKJ, Insitut Kesenian Jakarta). Pada tahun 1977, Seno mulai bekerja sebagai wartawan lepas pada surat kabar Merdeka. Tidak lama kemudian, ia menerbitkan majalah kampus yang bernama Cikini dan majalah film yang bernama Sinema Indonesia. Setelah itu, ia juga menerbitkan mingguan Zaman dan terakhir ikut menerbitkan kembali majalah berita Jakarta-Jakarta pada tahun 1985. Pekerjaan sebagai wartawan dijalani Seno sambil tetap menulis cerpen dan esai. Pada awal tahun 1992, Seno dibebastugaskan dari jabatan redaktur pelaksana Jakarta-Jakarta berkaitan dengan pemberitaan tentang insiden Dili pada tahun 1991. Selama menganggur, Seno kembali ke kampus yang ketika itu telah menjadi Fakultas Televisi dan Film, Institut Kesenian Jakarta. Ia menamatkan studinya dua tahun kemudian. Setelah sempat diperbantukan di tabloid Citra, pada akhir tahun 1993 Seno kembali diminta memimpin majalah Jakarta-Jakarta, yang telah berubah menjadi majalah hiburan.

Pada usia 17, ia bergabung dengan teater pimpinan Azwar A.N., Teater Alam. Sejak itu, ia terus terlibat dalam dunia kesenian. Seno memulai kegiatan 
sastranya dengan menulis puisi, cerita pendek, baru kemudian menulis esai. Puisinya yang pertama dimuat dalam rubrik "Puisi Lugu" majalah Aktuil asuhan Remy Silado. Cerpennya yang pertama dimuat di surat kabar Berita Nasional dan esainya yang pertama, tentang teater, dimuat di surat kabar Kedaulatan Rakyat. Seno kemudian mendirikan "pabrik tulisan" yang menerbitkan buku-buku puisi dan menjadi penyelenggara acara-acara kebudayaan. Hingga kini Seno telah menerbitkan belasan buku yang terdiri kumpulan sajak, kumpulan cerpen, kumpulan esai, novel, dan karya nonfiksi. Berikut ini adalah beberapa karya-karya Seno Gumira sebagai berikut.

1) Kumpulan Cerpen: Manusia Kamar (1988), Matinya Seorang Penari Telanjang (1988), Penembak Misterius (1993), Saksi Mata (1994), Dilarang Menyanyi di Kamar Mandi (1995), Negeri Kabut (1996), Sebuah Pertanyaan untuk Cinta (1996), Iblis Tidak Pernah Mati (1999), Atas nama Malam (1999), Dunia Sukab (2001), Kematian Donny Osmond (2001), Karangan Bunga dari Menteri (2011), Sepotong Senja untuk Pacarku (2002), Aku Kesepian Sayang Datanglah menjelang kematian (2004), Dilarang Menyanyi di Kamar Mandi edisi kedua (2006), dan Linguae (2007).

2) Novel: Jazz, Parfum dan Insiden (1996), Wisanggeni Sang Buronan (2000), Negeri Senja (2003), Kitab Omong Kosong (2004), Biola tak Berdawai (2004), Kalatidha (2007), Nagabumi 1: Jurus Tanpa Bentuk (2009) dll.

3) Puisi: Mati Mati Mati (1975), Bayi Mati (1978), dan Catatan-Catatan Mira Sato (1978).
4) Esai: Ketika Jurnalisme Dibungkam, Sastra Harus Bicara (1997).

5) Nonfiksi: "Cara Bertutur dalam Film Indonesia: Menengok 20 Skenario Pemenang Citra FFI 1973-1992" (Skripsi, IKJ, 1997), Surat dari Palmerah (2002), Affair Obrolan tentang Jakarta (2004), Sembilan Wali dan Siti Jenar (2007), dan Kentut Kosmopolitan (2008).

6) Drama: Mengapa Kau Culik Anak Kami?

7) Komik: Jakarta 2039 (2001), Taxi Blues (2001), Sukab Intel Melayu: Misteri Harta Centini (2002), dan Panji Tengkorak: Kebudayaan dalam Perbincangan (2011).

\section{Kritik Sosial dalam Cerpen "Karangan Bunga dari Menteri" Karya Seno Gumira}

Hakikatnya fenomena sosial itu bersifat konkret, terjadi di sekeliling kita sehari-hari, dan dapat diobservasi, difoto, dan didokumentasikan. Fenomena itu oleh pengarang diangkat kembali menjadi wacana baru dengan proses kreatif (pengamatan, analisis, interpretasi, refleksi, imajinasi, evaluasi, dan sebagainya) dalam bentuk karya sastra. Cerpen "Karangan Bunga dari Menteri" karya Seno Gumira Ajidarma merupakan cerpen yang sarat dengan kritik sosial terhadap kehidupan para petinggi atau pejabat negara. Dalam hal ini, Seno menyimbolkannya dalam sosok seorang menteri yang sangat sibuk dengan urusan pekerjaannya sehingga menganggap undangan perkawinan yang dialamatkan padanya tidaklah penting. Hal ini dapat dibuktikan dalam cuplikan berikut.

Seorang sekretaris tua, seorang perempuan dengan seragam pegawai negeri yang seperti sudah waktunya 
pensiun, membawa tumpukan surat yang sudah dipilahnya ke ruangan menteri.

Ia belum lagi membuka mulut, ketika menteri yang rambutnya tak boleh tertiup angin itu sudah berujar dengan kesal melihat tumpukan surat tersebut.

"Hmmmhh! Lagi-lagi undangan kawin?"

"Kan musim kawin, Pak," sahut sekretaris tua itu dengan cuek. Sudah lima menteri silih berganti memanfaatkan pengalamannya sehingga ada kalanya ia memang seperti ngelunjak.

"Musim kawin? Jaing kali'!"

Namanya juga menteri reformasi, doi sudah empet dengan basa-basi. Ia terus saja mengomel sambil menengok tumpukan kartu undangan yang diserahkan itu. Satu per satu dilemparkannya dengan kesal.

Dari kutipan tersebut dapat dicermati bahwa fenomena mengundang menteri dalam pesta perkawinan memang menjadi sebuah wacana tersendiri, terutama di kota-kota besar saat ini. Dalam bagian cuplikan tersebut, juga dapat ditangkap bahwa tidak semua menteri senang mendapat undangan yang bertumpuk dan banyak. Di sisi lain, gengsi kadang dipertaruhkan oleh si empunya hajat jika mendapat kiriman karangan bunga dari seorang menteri. Alangkah lebih bangganya lagi kalau tamu kehormatan tersebut benar-benar datang di perhelatannya.

Dalam teks cerpen ini, memang benar sang menteri mengirimkan karangan bunga sebagai penghormatan dan pengganti ketidakhadirannya dengan alasan sibuk. Seno mencoba mengungkap ide atau permasalahan yang berupa kritik terhadap pemerintah. Dalam hal ini, ia menghadirkan tokoh yang secara gamblang disebut menteri, yaitu seseorang yang menjabat sebagai kepala sebuah departemen (anggota kabinet) yang juga merupakan pembantu kepala negara dalam urusan (pekerjaan) negara, simbol dari kedudukan yang tinggi dalam pemerintahan. Hadirnya tokoh menteri di sini semakin menguatkan bahwa cerpen ini berusaha memberikan kritik terhadap pemerintah. Terlebih kritikan disampaikan dengan menggambarkan bagaimana kehidupan sebagai menteri yang merupakan tokoh terpandang dan sangat dihormati.

Sebuah kejadian yang terjadi di masyarakat reformasi tersebut inilah yang disebut dengan kesombongan sosial. Pada hakikatnya sastrawan pun merupakan bagian dari masyarakat. Sastrawan tidak dapat lepas dari status sosial tertentu. Sastra merupakan lembaga sosial yang mempergunakan bahasa sebagai mediumnya dan bahasa merupakan hasil cipta sosial. Perhatikan kutipan berikut.

"Kan Bapak belum bilang mau menghadiri undangan yang mana."

"Hadir? Untuk apa? Cuma foto bersama terus pergi lagi begitu," kata menteri itu seperti ngedumel lagi.

"Jadi, seperti biasanya? Kirim karangan bunga saja?"

"Iyalah."

"Bapak tidak ingin tahu siapa-siapa saja yang mengundang?"

"Huh!"

Dari kutipan tersebut, dapat dijelaskan bahwa dialog tersebut merupakan percakapan sang menteri dengan asisten pribadinya di ruangan menteri tersebut. Apakah hal ini tidak terlalu tendensius dengan menghubungkan karya sastra dengan kenyataan sosial saat ini? Inilah persoalan yang dikupas dalam pendekatan sosiologi sastra. Sastra diciptakan untuk dinikmati, dipahami, dan dimanfaatkan oleh masyarakat. 
Sudah sejak dulu karya sastra dikenal dalam beberapa tindakan sosiokultural masyarakat seperti pada upacara keagamaan, ilmu gaib, pekerjaan seharihari atau permainan. Ketika membaca sebuah karya sastra, mungkin pembaca akan merasakan kenikmatan seperti pembaca sedang melakukan permainan, merasakan ketenangan seperti setelah melakukan upacara keagamaan, bahkan merasa ikut terlibat dalam karya itu sendiri sebagai tokoh yang diceritakan. Sastra dapat mengandung gagasan yang mungkin dimanfaatkan untuk menumbuhkan karakter sosial tertentu atau untuk mencetuskan peristiwa sosial tertentu. Perhatikan kutipan berikut.

Pertama tentu pesanan kepada pembuat karangan bunga. Karangan bunga? Hmm. Maksudnya tentu bukan ikebana yang artistik karena sentuhan rasa, yang sepintas lalu sederhana, tetapi mengarahkan pembayangan secara luar biasa. Bukan. Ini karangan bunga tanpa karangan. Tetap sahih meskipun buruk rupa, karena yang penting adalah tulisan dengan aksara besar sebagai ucapan selamat dari siapa, dan dari siapa lagi jika bukan dari Menteri Negara Urusan Kemajuan Negara Bapak Sarjana Pa.B (Pokoknya Asal Bergelar), yang berbunyi SELAMAT \& SUCCESS ATAS PERNIKAHAN PAIMO \& TULKIYEM, putra-putri Bapak Pengoloran Sa.L (Sarjana Asal Lulus) Direktur PT Sogok bin Komisi \& Co.

Dalam kutipan ini, dapat dilihat sikap sebagai pembaca dalam memahami gejala kemasyarakatan ini. Dalam pendekatan sosiologi sastra, hal yang dianggap penting itu adalah hal yang dapat mengubah hubungan sosial. Pengarang besar tentu saja tidak sekadar menggambarkan kondisi sosial secara mentah. Sastra karya pengarang besar melukiskan kecemasan, harapan, dan aspirasi manusia. Barangkali ia merupakan salah satu barometer sosiologis yang paling efektif untuk mengukur tanggapan manusia terhadap kekuatan sosial. Sastra juga akan selalu mencerminkan nilai-nilai dan perasaan sosial. Oleh karena itu, pembaca dapat memosisikan dirinya di dalam teks sastra sebagai pelaku pasif yang memberikan tanggapan positif dan negatif dalam dirinya. Perhatikan kutipan berikut.

Tiga karangan bunga dari menteri, karena datangnya cukup siang, berada jauh di urutan belakang, nyaris di dekat pintu masuk ke tempat parkir di lantai dasar. Siti tentu saja tahu suaminya telah mengundang tiga orang menteri, yang proyek-proyek kementeriannya sedang ditangani perusahaan suaminya itu. Suaminya hanya kenal baik dengan para pembantu menteri tersebut, meski hanya tanda tangan menteri dapat membuat proyeknya menggelinding. Tentu pernah juga mereka berdua berada dalam suatu rapat bersama orang-orang lain, tetapi sudah jelas bahwa menteri yang mana pun bukanlah kawan apalagi sahabat dari suaminya itu. Sama sekali bukan.

Namun ketika suaminya datang memeriksa, Siti terpana melihat perilakunya. Itulah, setelah 25 tahun pernikahan, masih ada yang ternyata belum dikenalnya.

Suaminya, yang agak gusar melihat tiga karangan bunga dari tiga menteri saling terpencar dan berada jauh dari pintu masuk, memerintahkan sejumlah pekerja untuk mengambilnya. Ia mengawasi sendiri, agar terjamin bahwa ketika melewati pintu masuk, setiap tamu yang datang akan menyaksikan betapa terdapat kiriman karangan bunga dari tiga menteri. 
Dalam kutipan ini dapat dapat dikatakan bahwa sebuah tingkah laku overacting social. Seorang suami yang sudah lama menjadi mitra istrinya menjadi asing di mata istrinya karena karangan bunga dari menteri. Dalam sosiologi sastra, sastra menyajikan gambaran kehidupan dan kehidupan sebagian besar berasal dari kenyataan sosial. Dalam pengertian ini, segala hal yang mencakup hubungan antar masyarakat dengan orang-orang, antar manusia, antarperistiwa yang terjadi dalam batin seseorang. Oleh sebab itu, memandang karya sastra sebagai penggambaran dunia dan kehidupan manusia, kriteria utama yang dikenakan pada karya sastra adalah "kebenaran" penggambaran atau yang hendak digambarkan. Namun, Wellek dan Warren (2014:100) mengingatkan bahwa karya sastra memang mengekspresikan kehidupan, tetapi keliru kalau dianggap mengekspresikan selengkap-lengkapnya.

Terdapat rangkaian penting yang bisa jadi merupakan sebuah sebab-akibat dalam cerpen ini. Pembaca dapat melihat kecenderungan masyarakat kalangan atas menganggap sebuah status yang disimbolkan oleh karangan bunga dari seorang menteri atau rekanannya merupakan harga diri dan tentu saja sebagai bentuk ungkapan rasa "terima kasih". Jika membaca judul cerpen ini, tergambar ide yang diwakili oleh dua simbol, yakni istilah karangan bunga dan menteri. Keduanya saling berintegrasi. Selain menjadi simbol kehormatan, menteri juga menjadi simbol ketidakpedulian para petinggi negara dengan masyarakat. Selanjutnya, kedua simbol ini di balik atau dikeluarkan dari makna strukturnya sehingga diperoleh gagasan baru. Tidak menjadi masalah jika tidak dihadiri menteri, asal para tamu melihat sendiri, bahwa memang ada karangan bunga dari menteri. Ini juga berarti para pengundang meski yang diundang adalah sang menteri, yang datang karangan bunga pun jadi.

Seorang menteri dalam cerpen ini tidak langsung menunjukkan sebuah jabatan "menteri", tetapi menjadi simbol para petinggi negara atau pejabat pemerintahan. Jabatan yang tinggi membuat banyak orang yang menaruh rasa hormat padanya. Mereka juga akan merasa terhormat jika dapat dekat atau bahkan hanya sekadar kenal dengan orang yang memiliki jabatan tinggi di pemerintahan.

Kenyataan dalam masyarakat yang memandang status seseorang hanya dari luarnya saja, dari simbol yang seharusnya bukan merupakan hal penting. Terkait dengan cerpen ini, belum tentu menteri yang menerima undangan perkawinan merasa senang mendapat undangan tersebut. Lebih dari itu, suatu kondisi juga dianggap sebagai masalah sosial karena menimbulkan berbagai penderitaan dan kerugian. Padahal, di lain pihak, si empunya hayat sudah merasa dapat durian runtuh walaupun hanya karangan bunga yang dating.

"Kan Bapak belum bilang mau menghadiri undangan yang mana."

"Hadir? Untuk apa? Cuma foto bersama terus pergi lagi begitu," kata menteri itu seperti ngedumel lagi.

"Jadi, seperti biasanya? Kirim karangan bunga saja?"

"Iyalah."

"Bapak tidak ingin tahu siapa-siapa saja yang mengundang?"

"Huh!"

Sekretaris tua itu segera menghilang ke balik pintu. Menteri itu menggeleng-gelengkan kepala tak habis mengerti. Kadang-kadang orang yang mengawinkan anak ini tak cukup hanya mengirim undangan, melainkan datang sendiri melalui segala saluran dan berbagai cara, 
demi perjuangan untuk mengundang dengan terbungkuk-bungkuk, agar bapak menteri yang terhormat sudi datang ke acara pernikahan anak mereka.

Apakah pengantin itu yang telah memohon kepada orangtuanya, agar pokoknya ada seorang menteri menghadiri pernikahan mereka? "Jelas tidak!"

Menteri itu terkejut mendengar suaranya sendiri. Ia merasa bersyukur karena sekretaris tua yang tiba-tiba muncul lagi itu tidak mendengarnya.

Dalam kutipan ini, dapat dapat dilihat bahwa posisi si pengarang dalam pendekatan sosiologi sastra ini menampilkan gambaran kehidupan dan kehidupan itu sendiri adalah suatu kenyataan sosial. Dalam pengertian ini, kehidupan mencakup hubungan antarmasyarakat, antara masyarakat dan individu antarmanusia dan antarperistiwa yang terjadi dalam batin seseorang. Bagaimanapun juga, peristiwa yang terjadi dalam batin seseorang sering menjadi bahan penulisan sastra, yang merupakan pantulan hubungan seseorang dengan orang lain atau dengan masyarakat dan menumbuhkan sikap sosial atau peristiwa sosial tertentu. Jadi, jelaslah bahwa posisi pengarang dalam karya sastra merupakan cerminan dari olah batin pribadinya. Hasil sebuah perenungan dari kenyataan sosial di lingkungan, terlepas ada atau tidaknya kejadian di dunia nyata, dunia sebenarnya.

Terdapat sisi lain yang digambarkan Seno. Para pejabat dapat saja mengirimkan karangan bunga hanya untuk menjaga citraan dirinya. Seno juga mengungkapkan pola pikir masyarakat yang terlalu mengagungkan para pejabat yang sebenarnya adalah pelayan masyarakat. Selain itu, pengarang memiliki maksud lain dari sekadar menyuguhkan sebuah cerita yang memang tertera secara nyata di dalam teks sebuah karya sastra. Maksud lain dari penceritaan dalam cerpen "Karangan Bunga dari Menteri" adalah mengajak pembaca untuk lebih membuka mata dan sadar bahwa mereka sedang hidup dalam kekacauan pemerintahan. Tokoh yang digambarkan hanya memperhatikan kekuasaan tanpa peduli dengan lingkungan atau masyarakat sekitar. Kekuasaan terletak pada sebuah kehidupan seorang menteri yang membanggakan kekuasaan adalah yang di atas segala-galanya. Pengarang menggambarkan langsung tokoh atau objek yang dimaksud dengan ide tokoh yang menganggap masyarakat hanya sebagai batu loncatan hanya untuk memiliki kekuasaan. Kedudukan masyarakat hanya sekadar formalitas saja. Masyarakat dianggap tidak penting, yang terpenting bagi seorang menteri adalah bagaimana cara bekerja demi satu kepentingan saja. yaitu kedudukannya. Kondisi hubungan antara orang yang memiliki jabatan tinggi dalam pemerintahan dengan masyarakat biasa sering terjadi gesekan. Tidak selamanya hal yang terlihat baik itu memang baik. Bisa saja semua itu hanyalah kepalsuan belaka.

Apakah ini juga bisa jadi berlaku di lingkungan atau negara kita? Untuk menjawab pertanyaan ini akan muncul lagi pertanyaan baru, apakah sudah demikian parahnya proyeksi status manusia di era reformasi ini? Apakah status seseorang dapat ditingkatkan hanya dengan sebuah karangan bunga dari seorang yang berstatus lebih tinggi? Jadi, terlepas dari fenomena ada dan tidaknya kejadian ini, semuanya kembali ke dalam pergulatan batin pembacanya sebagai salah satu media yang memperkaya khasanah kebatinan pembaca. 


\section{PENUTUP}

Berdasarkan hasil pembahasan dapat ditarik simpulan bahwa cerpen cerpen "Karangan Bunga dari Menteri" karyaSeno Gumira Ajidarma mengandung kritik sosial yang dimunculkan dari percakapan para tokoh dan juga melalui narasinya. Cerpen tersebut merupakan cerpen sindiran mengenai perilaku masyarakat pada saat cerpen ini dibuat. Sindiran tersebut dapat terlihat dari unsur kritik sosial yang disisipkan dalam dialog tokoh. Kritik sosial tersebut mencakup bahwa adalah sebuah kenyataan yang sedang menjadi fenomena di tengah masyarakat tentang perilaku sebagian pejabat negara yang gila hormat, angkuh, dan suka menyalahgunakan kewenangannya.

Demikian juga terdapat perilaku anggota masyarakat dengan cara melakukan pendekatan pada pejabat negara dengan maksud untuk memperoleh kemudahan atau kemajuan usahanya. Perilaku yang tidak terpuji itu, apalagi pada masa sekarang ini, sepatutnya diubah atau direformasi demi kemajuan dan kemaslahatan negera. Perubahan sikap buruk menjadi sikap terhormat bisa dimulai dari diri sendiri, selain juga menjadi tanggung jawab penegak hukum dan bahkan tanggung jawab bersama segenap lapisan masyarakat.

\section{DAFTAR PUSTAKA}

Ajidarma, S. Gumira. (2011). Karangan Bunga dari Menteri. Jakarta: Kompas, p. 14.

Damono, S. Djoko. (2003). Sosiologi sastra. Semarang: Magister Ilmu Susastra Universitas Diponegoro.
Devi, K. (2013). Analisis perbandingan teori hegemoni cerpen "Karangan Bunga Dari Menteri" karya Seno Gumira Ajidarma dengan cerpen "Pemburu" karya Agus Noor. Diperoleh dari http://devizung.blogspot.com/201 3/11/analisis-perbandingan-teorihegemoni.html

Ekasaputra, A. (2018). Drupadi sebagai simbol perlawanan terhadap kuasa patriarki dalam novel Drupadi: Perempuan Poliandris karya Seno Gumira Ajidarma. Jurnal Student UNY, 7(3), 313324.

Endraswara, S. (2012). Teori sosiologi sastra. Yogyakarta: UNY Press.

Endraswara, S. (2013). Metodologi kritik sastra. Yogyakarta: Ombak.

Endraswara, S.. (2019). Menaklukkan pohon kritis, Pengantar teori kritis dan metodologi dinamika bahasa, sastra dan budaya. Yogyakarta: Kepel Press.

Fananie, Z. (2002). Telaah sastra. Surakarta: Muhammadiyah University Press.

Faruk. (2012). Pengantar sosiologi sastra. Yogyakarta: Pustaka Pelajar.

Jabrohim. dkk. (2001). Metodologi penelitian sastra. Yogyakarta: Hanindita Graha Widia.

Jenks, C. (2013). Culture: Studi kebudayaan. Yogyakarta: Pustaka Pelajar.

Kartono. (2013). Masalah sosial dan upaya pemecahannya. Yogyakarta: Pustaka Pelajar.

Kosasih, E. (2012). Dasar-dasar keterampilan bersastra. Bandung: Yrama Widya. 
Nurgiyantoro, B. (2010). Teori pengkajian fiksi. Yogyakarta: Gajah Mada University Press.

Priyatni, E. T. (2010). Membaca sastra dengan ancangan literasi kritis. Jakarta: Bumi Aksara.

Rahman, M. A. (2018). Komparasi dekonstruksi simbolisme dalam cerpen Padang Kurusetra karya Emha Ainun Nadjib dan Karangan Bunga dari Menteri Karya Seno Gumira Ajidarma. Jurnal Mahasiswa Pendidikan Bahasa Indonesia, 1(1), 2-10.
Sarjono, A. R. (2001). Sastra dalam empat orba. Yogyakarta: Bentang. Yogyakarta: Bentang.

Sobur, A. (2009). Semiotika komunikasi. Bandung: PT Remaja Rosdakarya.

Suyanto. (2012). Perilaku tokoh dalam cerpen Indonesia. Bandar Lampung: Universitas Lampung.

Wellek, R., dan A. Warren. (2014). Teori kesusastraan. Jakarta: Gramedia Pustaka Utama. 